DOI: $10.15503 /$ jecs20162.262.273

\title{
SPATIAL TURN AND ANIMATION PRACTICES INSPIRED BY CULTURAL ANTHROPOLOGY
}

\author{
AGNIESZKA WIESZACZEWSKA \\ Faculty of History and Pedagogy, University of Wrocław, \\ Uniwersytecki Square 1, 50-137 Wrocław, Poland. \\ E-mail address: agnieszka.wieszaczewska@uwr.edu.pl
}

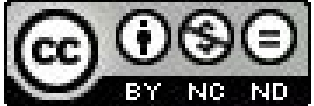

\begin{abstract}
Spatial turn is one of the cultural turns, which have recently occurred in the humanities. It stresses the importance of issues such as space and place and can be successfully used as a theoretical perspective gaining use in thought over issues such as globalisation, transnationality, mapping but also education. In the discourses of pedagogical science space and place are considered through their multidimensional impact on education and learning. As significant concepts rooting pedagogy or pedagogy of borderland. The pedagogical reflection on space could be also used in the field of animation practices, especially in activities, which are related to place somehow colonised.
\end{abstract}

Key words: space, pedagogy of space, spatial turn, cultural animation.

\section{INTRODUCTION. SPACE AS CULTURAL PHENOMENA}

Space and time are considered to be the basic and universal categories of human cognition. In all cultures, we can find ways of getting accustomed to them through expressing them in words, conceptualizing and capturing and declaring in cosmogonist myths, which ought to explain the most important dimensions of human existence. Ernst Cassirer has downright claimed, that "time and space constitute a framework, which enclose a whole reality. We cannot comprehend any real object in a category other than conditions of time and space" (Cassirer, 1998, p. 92). Although both time and space are parts of physical and objective world, which surrounds humans, it is necessary to remember that from the very moment of terming these two phenomena, they have entered the world of the cultural meanings and are currently understood through them. The latter are also recognized by some larger groups (the civilizational, national, religious ones...); however their experiences are also individual and specific for every member of a given community. "Space being subject of humanities' interest is not an abstract notion - clear and pure form - but rather a social category having cultural meaning. Space introduced into a culture sphere 
starts to (...) function as a sign reality, therefore gains a specific meaning and is contained to a meaning sphere. Thus cultural space is neither homogenous nor neutral, but rather individually and qualitatively diversified" (Węglarz, 2003, p. 23).

Much has been written on the significance of space for the human cognition, however over the centuries it was time, which had a prevailing role in Western culture. Development, progress, ascending towards heights of the civilisation as time passes by: this was the most frequent way of expressing and describing the history of mankind (obviously from the Western perspective, however at the end of the day it was the perspective which turned out to prevail, firstly through expansion and military conquests, and today - through globalization processes affecting almost every corner of the world). Space was mentioned almost only alongside. Dominance over space was kind of consequence of the development, which lasted over time.

Since world of culture preferred thinking in time categories over space, world of science did likewise and preferred to temporalise rather than spatialise. A breach in the aforementioned perception of the world and huma$\mathrm{n}$ 's position therein has come relatively late, and yet it has restored proper place of the space within scientific consideration of the culture. Bachamann-Medick is placing this qualitative change just at the end of the past century, when „Frederic Jameson, American cultural theorist, outstanding representative of postmodernism, has come up with a slogan: «Always spatialise!». This call to spatialise as a method is implied by the way postmodernism is being defined by itself, that is by space oriented understanding, which as one can assume, ought to replace dominating postmodern orientation on time" (Bachmann-Medick, 2012, p. 335). This radical change in perception of space has been called spatial turn and under such name has been permanent part of the humanities discourse.

\section{SPATIAL TURN - THEORETICAL CONTEXT OF REFLECTIONS}

One of the turns that arrived recently in humanistic sciences was so called spatial turn understood as a turn towards space. Space became important, it draws our attention more and more, most notably in academic discussions $^{1}$. After years of domination of temporality, history, evolution, there came a moment when "'space' has become a central new unit of perception as well as a theoretical concept" (Bachmann-Medick, 2016, p. 211). In connection with the spatial turn, reclamation of space takes place; space that has been, for various reasons, colonised, effaced or consigned to the scrapheap.

1 Emergence, in the last few years, of publications referring to public space - especially those alluding to necessity of caring for it not only in a practical but also in an aesthetic sense - seems symptomatic. Space in which we live affects our aesthetic sense, relations with a place and with other people, shapes tastes and choices. See e.g. Springer, 2013; Kędziorek, Springer, \& Smaga, 2014; Rybczyński, 2014. 
In the context of the spatial turn, issues of contemporaneity and action are also becoming more and more significant.

The term 'spatial turn' by itself is problematic and often it is impossible to unequivocally determine if it brought about some fundamental pragmatic change in humanistic sciences; this is also connected to certain kind of present redundancy of turns: "excess of turns in contemporary humanistic sciences can lead to their inflation or, as others suggest, to pacing in place or returning to the starting point. (...) In the Polish context, it is precisely the spatial/topographical turn that seems the most problematic - as in Polish terminology neither of the two variants of the name has been yet firmly established or even popularised and its status may be called into question" (Rybicka, 2008, p. 21). Magdalena Marszałek also wonders if it is justified to say that "interest in geography as well as topo- and cartographic techniques creates a new paradigm in historical and culture-related research" (Marszałek, 2007, p. 540).

Transformations of the contemporary reality bring about, on the one hand, changes in existing borderlines and constant emergence of newer spatial dependencies and configurations as well as, on the other hand, processes leading to the fact that following diagnosis seems completely justified: "space is disappearing! After all, the simultaneous phenomena of global despatialization and delocalization are obvious. The rampant rise of telecommunications and other information media such as email and the Internet, their translocal dissemination, the compression of space through speed, the transcendence of distances - all have led to the perception of the world as a global village" (Bachmann-Medick, 2016, p. 213). Along with the gradual fall of the grand narratives, such oppositions as centre-periphery also diminished, which is particularly visible in the postcolonial efforts to disenchant the once appropriated and orderly fragments of space. Hence, spatial turn is connected to practices of remapping and rewriting places and their inhabitants once dominated by official European discourses. But it does not end here. Cogitation of space may also appear in reflections on transnationality and is a basis of the Thirdspace concept introduced by Edward Soja (Soja, 1996).

In the paper the author will propose the analyse of space in the context of contemporary discourses on cultural animation. The author's interest concerns the question how different discourses related to this issue conceptualise and describe space; however, the main focus will be efforts of animators, who base their operations in very specific local spaces.

\section{CATEGORY OF PLACE IN PEDAGOGICAL DISCOURSES}

Interest in space has always existed in pedagogy, even if only due to the fact that all practices (including those related to education) must be conducted in some place, be affixed, defined in space. "Somewhere events 
unfold, somewhere senses fall into place - through them we comprehend reality and ourselves in it with more or less clear but always present sense of being connected to the place" (Mendel, 2006, p. 21). Ilona Copik (Copik, 2013 , p. 179) remarks that place is not a subject of pedagogical considerations all that often, despite its undeniable pertinence in various educational processes. She also emphasises that place should always be considered in connection with all the social meanings associated with it and not only as a fragment of space defined by latitude and longitude. Those meanings are conferred by "man in his individual and social experiences" (Copik, 2013, p. 180). Human being is connected to a place in more ways than one, what is exemplified, inter alia, by the term 'private homeland' used by Stanisław Ossowski (1984), one of the most important categories of cognitive anthropology - friend/stranger (and a directly connected to it division into a world tamed, familiar and all the terrain that lies beneath - seen as alien, mysterious, and even dangerous), or considerations of Edward Thitchell Hall on perception of space in various cultures (Hall, 1990). A need to settle down, to domesticate was also contemplated by Yi-Fu Tuan, a prominent expert in the field, who also firmly demarcates between place and space (Tuan, 2001), as well as by Martin Heidegger (Heidegger, 1975). Pedagogy of place itself, inspired by anthropological thought and phenomenology of place, "assumes (...) on the one hand, obligatorily educative role of a place, which conditions present process in various ways, 'shapes' its pupil, as it were; and on the other hand, its capacity for inducing reflection, stimulating activity and critical thinking" (Copik, 2013, pp. 182-183). Maria Mendel emphasizes this dual character of thinking about a place, assuming that a place is always pedagogical (Mendel, 2006).

Pedagogy of place, as a theoretical perspective on the subject of humanspace/place relations, problematizes issues concerning connection between learning processes and a place where they occur, meaning that people impart on a place during education, as well as becoming rooted. It can also be a strategy of "creating a subject through a place and as such, it can successfully limit areas of education - school (formal) as well as informal - aimed at children, youth, and adults" (Mendel, 2006, p. 27). Such pedagogy can also provide some sort of perspective on how a place affects a subject that experiences it.

From a pedagogical perspective a place deserves attention especially because, as Astrid Męczkowska observes, it is "as a space of experiencing the world, a space significant for processes of constructing identity of the subjects - [in a sense that] identity of a person is not created in specific places but rather in relation to those places" (Męczkowska, 2005, p. 39). Many theoreticians and social researchers argue that, despite all the changes brought on by globalisation, an individual still feels strongly connected to a place, which can be understood in the educational processes as rooting the pupils in a specific cultural space. Role of a place is viewed completely differently from the perspective of a global society idea related to educational policies of the European Union. 
"In case of the European Union's policy related to realisation of the society of knowledge idea, base for identity rooting (...) is reality of the social world viewed through the prism of social-economical aspects. It is a place in relation to which a new European identity should be created; an identity that eclipses local (ethnic, cultural) differences between groups of people" (Męczkowska, 2005, pp. 46-47).

Apart from the projects of rooting education, more and more often we can see postulates of focusing educational activities in the space of difference, which will allow the subject to successfully function in conditions of cultural diversity. Ability of thinking critically on the offered identities can be shaped during such educational practices, which emphasise variety and multitude of borders. Lech Witkowski argues that "a place seen translocally means subordination to concerns about saturation with difference understood as wealth and opportunity to facilitate dealing with complexity of the world outside of this place (frontier effect)" (Witkowski, 2001, p. 55).

What is also important in my deliberations is referring to the educational dimension of the biography of a place, which sets reflections about space in a very local context and can be understood in three ways. Firstly, the biography of a place can be understood as a kind of official description of this particular space, facts from its past. Secondly, it can be description of a place from the perspective of people inside - its inhabitants. And lastly, it can pertain to people alien in this space, including researchers that turned their attention to this particular fragment of terrain for some reason. Animation practices, which will be described further in this paper, are largely focused on a place experienced by its inhabitants, so on the emic approach. They are, however, also very sensitive to the fact that the bibliography of a place can be used to dominate discourses on space and its appropriation.

"[I]n many cases, education - though a dominant 'biography of a place' - can become (...) a tool of hidden violence against the inhabitants. Learning through an obligatory, dominant 'biography of a place' ensures continuity of the local community, its history, structures, values, and specificity of a place. However, dominant histories of a place are not always able to function freely, without emergence of barriers usually affecting places where history was hidden or falsified. This is especially visible in settlements, where political decisions resulted in deportations, migrations, and resettlements" (Kurantowicz, 2006, p. 79).

The place is significant in a life of a person and plays an important role in constructing his/her identity. For that reason, it should be of continuing interest to pedagogy - in its broader aspect as well as a local one. Further in this paper, two animation initiatives will be described that can be considered educational activities sensitive to the category of place. 


\section{RESEARCH/ACTION - EXEMPLIFICATION OF ANIMATION PRACTICES INSPIRED BY ANTHROPOLOGY}

Interest in space opened a way for a lot of activities in the area of pedagogy, animation, and cultural anthropology. Commitment turn, more and more present in the academic circles, allows for existence of initiatives from the research-action borderline. This type of activity - once mainly characteristic of pedagogy and situated in the area of art - nowadays broadens its circles of involved subjects, concomitantly redefining itself in order to make animation more adequate to contemporaneity. Małgorzata Kopczyńska defined social-cultural animation as "spreading 'high culture', free time activities, as well as stimulating and animating new folk culture, i.e. non-professional artistic output in the broadest sense of the word" (Kopczyńska, 1993, pp. 9-10). This definition runs the risk of encasing the activity of animators in rigid framework of artistic operations, professional as well as non-professional ones.

Animation practitioners - notably, but not exclusively, those who originated in the circles of cultural anthropology - do not concur with this narrow understanding of cultural animation. This objection to artistic-educational vision of the animation is expressed by, among others, Grzegorz Godlewski (2008), Małgorzata Litwinowicz (2008), and Tomasz Rakowski (2013). They propose solutions far beyond the commonplace pattern, alluding to such concepts as local knowledge, active culture, community arts or New Culture ${ }^{2}$. Grzegorz Godlewski recalls beginnings of the anthropological thought - as well as practice - of cultural animation, connected to emergence of institutions that educated students in this area: "when at the beginning of the ' 90 , after years of cogitation, experience, and preparation, we introduced in the Department (nowadays - Institute) of Polish Culture of the University of Warsaw the Cultural Animation specialisation, we were all indeed confident that it is needed and maybe even necessary complement to anthropologically-oriented programme of knowledge of culture, which we collaboratively taught in classes and realised, everyone in his/her own way, in our research practice. However, we were identifying the character of this relationship rather intuitively - with the force of empirical obviousness. On the one hand, the cultural reality we were researching - in its practical expressions as well as theoretical conceptualisations - could not be simply fitted into the limits of one piece of work or text and was provoking thinking about culture in the categories of atavism, cultural attitudes, activities. On the other hand, fellow creators and practitioners of culture (although this division was becoming more and more questionable) in their achievements (...) were not only breaching the borderlines of aesthetics and art fields but also the borderline separating artistic culture from the whole of cultural experience, the borderline between a creator, his work and its recipient, between creative output, cognition, and action" (Godlewski, 2008, p. 4).

2 New Culture as a method of animation co-created by Marek Sztark I will discuss in later parts of this paper. 
In the statement above, artistic space is not a dominant field of animation activity, which is extended onto the whole cultural experience. This position is shared by the increasing number of representatives of the animation circles - especially those rooted in anthropological tradition ${ }^{3}$. Evidently, classical understanding of duties and goals of animation is still present. However, overcoming the domination of artistic-educational discourse allowed the start of a broader discussion among practitioners and theoreticians of animation.

Anthropologists actively involved in animation raise another important issue - the existing division of Polish city space into cultural centres and periphery. Tomasz Rakowski, who in 2008 and 2009 carried out two projects 'Miejsce wspólne' ['A common place'] and 'Trzy bieguny' ['Three Poles'], writes: "we cannot pretend otherwise - in our ethnographic-animation endeavour we are faced with certain common social imagination, in which social and cultural life of Polish villages is seen as incomplete, retarded, requiring education and correctional programme" (Rakowski, 2013 , p. 8). In narrations about cultural condition of Polish villages, we can often meet with belief that beyond regional municipal centres there is practically no culture - it is the same way in common knowledge, official knowledge (especially clerical one connected to operating in the field of national heritage and culture), academic knowledge or knowledge shared by the animators themselves, often those operating in non-governmental sectors. This belief is reinforced also by reports concerning participation in culture - they often state that outside of big cities the inhabitants essentially do not participate in culture.

Tomasz Rakowski says that motivation for his projects conducted in Ostałówka and Bronów was necessity to undertake initiatives that can operate against "cultural colonisation" and processes named by Michał Buchowski inner Orientalisation (Rakowski, 2013, p. 8); which are reproducing and solidifying the concept of a village as a cultural wasteland and an incomplete space that is in need of some correctional programme.

“This interpretation - reinforced by historical events, especially by the transition of many people from villages into 'city living' that happened in the second half of the $20^{\text {th }}$ century - has enormous potency. Under its influence, not only representatives of the dominant culture (interpreters of social life) but also village inhabitants themselves as well as village migrants start to - like in one of the examples given in in postcolonial theory textbooks - see themselves as people still stuck in a social waiting room, as a source of shame" (Rakowski, 2013, p. 8).

3 Good example is the fairly recent emergence of non-governmental organisations (mainly associations) that base on anthropological competencies and methods - such as Pracownia Duży Pokój[Workshop Big Room], Stowarzyszenie ‘Pracownia Etnograficzna' [Ethnographic Workshop Association], Stowarzyszenie Antropologiczne 'Archipelagi Kultury' [Archipelagos of Culture Anthropological Association], and others. 
Another danger lies in proposed correctional programmes blindly employing solutions from creative sectors. Validity of transforming experiences and cultural activities into elements that stimulate the economy and are driven by innovation, creativity, and flexibility is a concept created in an environment completely different from Polish villages; transferring it there can above all "revoke everything that is already present in those environments, such as their own local competencies and 'bottom-up creativity' functioning there in an incredible way, through 'constructing', 'finding', 'fitting', 'organising', 'making do' (Rakowski, 2013, p. 9).

An obvious ascertainment that "the world is becoming increasingly municipal - the number of people living in spaces classified as city spaces is growing" (Grochowski, 2013, p. 9) cannot serve as justification for this kind of transference or - what also sometimes happens - estimating participation in culture purely though quantitative parameters representing how often the inhabitants of the region made use of classically defined institutions of culture, such as libraries, theatres, cinemas of philharmonics. Emergence of reflection focused on spaces traditionally viewed as excluded from culture which has been also strongly rooted in activities since its beginnings - allows for thinking that there can be some re-evaluation of current division into cultural centres and periphery, not only in academia but also in animation practices and maybe even in clerical discourse.

Another interesting perspective, developed in the context of anthropologically-oriented cultural animation, is a proposal of Marek Sztark - a New Culture method. It is focused on specific spaces, which for one reason or another were excluded from use by local community and are considered inferior, shameful, unneeded. This method was first conceived:

"in the summer of 2001 in Czaplinek, when during 'Clashes with Architecture' workshop the cultural animators from all-over Poland were discussing exactly (...) gaps in the spatial order and taboo objects, an important document - declaration was signed (...). In it we read: 'Everybody has the right to a beautiful landscape, life in a healthy and harmonious environment', and later: 'every place tells us its story'. (...) those two postulates make up the foundation of the cultural animation method meant for places with disturbed spatial order, which has been later named New Culture" (Kłosowski, 2012, p. 88).

The main purpose of employing the New Culture method is to find a place - a gap in city space - and try to return it to this space. At the end of the project, an artistic event (such as concert, recital, exhibition) is organised in this place. Before that can be done, however, long and thoughtful work with local inhabitants is needed. Marek Sztark argues that disturbance in spatial order creates disturbances in social order: "people avoid looking at a particular place, something is not talked about in local community and that tears apart a whole web of trust between people" (Kłosowski, 2012, p. 88). A second founding belief of New Culture is that each place has a chance 
to change and the potential for this change is right there - in its inhabitants. Space here is not viewed as a container but rather as an open project. To put it simply, an animator who chooses to use Sztark's method in his/her work must first identify a place that has a grievous problem and then organise an artistic event there. Audience of this event should be comprised mainly not of the inhabitants of the place but of people from nearby cities and other settlements, who can travel some distance in order to attend the finale of this operation. Local community should take on a role of co-hosts; they are the most important in the whole event, because:

"mission of New Culture is not organising a concert or an exhibition by itself, but also drawing attention to the problematic place and inviting its inhabitants see this place from a new perspective. In this unusual space, a presentation of a work of art - recital, show, exhibition - takes place. A meeting with a prominent artist, a master in his field, is organised. (...) Audience form nearby cities is present - all of them sincerely interested and with high expectations as to the artistic level. So this event always has festive, ceremonial atmosphere rather than a ludic one. People usually perceive such event as something important. The event itself draws attention to the chosen place, its history and problems. (...) It once again incorporates into the flow of culture that what was hitherto dead, bashfully omitted, forgotten" (Kłosowski, 2012, pp. 90-91).

When using the New Culture method, the most important things happen before and after the event. A concert, a recital, an exhibition - all are just catalysts for change, which is meant to incorporate an existing space that has not yet realised its potential in the life of the community.

\section{PEDAGOGICAL ENDEAVOUR}

For years space had been dominated by discourses that not only leashed it but also produced and solidified division into 'superior' and 'inferior' places, into centres and periphery, into places where culture exists and thrives and where - paradoxically - it is supposed to be non-existent. Moreover, such a way of thinking about space is still present in many narrations associated with cultural animation and "in Poland there is a die-hard positivist, partly also rooted in times of the Polish People's Republic, belief in a mission of bringing education to the masses" (Althamer, Stokfiszewski, \& Żmijewski, 2011, p. 18). Animation activities inspired by an anthropological thought which is, in the opinion of Grzegorz Godlewski, already cited in this paper, "a kind of applied cultural anthropology" (Godlewski, 2005, p. 6) - are means of resisting such discourses. If community arts broadened the scope of artistic activities to encompass the audience, broke the schematic division into 'sender' and 'receiver', was a kind of an art of dialogue - then renewed interest in space in humanistic sciences and animation practices gives those 
degraded, aching, bashful or simply forgotten, omitted places a voice of their own. Spatial intermingling of cultural centres and periphery not only brings a breath of fresh air that opens animation practices to new possibilities but also gives new opportunities to fight stereotypical views (still present) on the subject of accessible culture, places deprived of culture or cultural springs, such as museums, concert halls, theatres. Spatial turn can be indeed defined as "committed postcolonial exploration of (marginal) spaces. Its aim is to (...) institute a policy of emphasizing local cultural practice and empowerment in opposition to the spatial hegemony of imperialism" (Bachmann-Medick, 2016, p. 215).

Presented initiatives, which engage the representatives of academia and happen on the grounds of animation, are an important voice on how contemporary reality produces spaces 'without culture', what is later solidified by various discourses and often supported by appropriate authority.

When we examine what issues are discussed in this context, we can clearly see that spatial turn and opening oneself to innovative animation practices is fully situated within the area of interest of critical pedagogy. Henry A. Giroux, one of the most known representatives of this movement in the world, asserts that "pedagogy should be a struggle against so called monumental forms, totalitarian forms, against narrations that give no possibility of distinctness" (Giroux, \& Witkowski, 2010, p. 68).

\section{CONCLUSIONS}

Activities presented in this paper can be considered reflective practices that strive for animating, stimulating some space - which is seen not only as a container (here, it seems, an empty container that should be filled with a pre-prepared appropriate cultural programme) but also as a project - as well as constructing activities though understanding of local discourses on that space, so: reclaiming it. Space looses its quantifiable character and the emphasis is rather placed on "the social production of space as a complex and often contradictory social process, a specific localization of cultural practices, a dynamic of social relations that points to the mutability of space" (Bachmann-Medick, 2016, p. 214).

In its humanistic aspect, cultural animation is unveiling the voices not yet heard or those that we did not even suspect existed. It will raise awareness of the polyphony of discourse on condition of Polish culture. Being aware of existence of different languages lays a groundwork for a non-limiting and non-total discussion about purposes and methods of contemporary cultural animation. In this context, presented activities have deeply humanistic character, as it is exactly "humanities that show us that there is no one dictionary that could be used to explain the world; there is no one supreme ideology (...), which we could employ; there is no pre-prepared collection of symbolic representations, more adequate than other collections. (...) We can treat 
humanities as sort of an unfinished project, existence of which is essential for our improved understanding of our actions. Not only in academia but also in every area of social life" (Markowski, 2011, p. 26-27).

\section{REFERENCES}

[1] Althamer P., Stokfiszewski I., \& Artur Żmijewski, Posłaniec, który nas budzi [The messenger, who wakes us up]. (2011). In: W. Kłosowski, (Ed.), Kierunek kultura. W stronę bardziej żywego uczestnictwa w kulturze [The culture direction. Towards more vivid participation in culture] (pp. 17-29), Warszawa: Mazowieckie Centrum Kultury i Sztuki.

[2] Bachmann-Medick, D. (2016). Cultural Turns. Nowe kierunki w naukach o kulturze [Cultural Turns. New Orientations in the Study of Culture]. Warszawa: Oficyna Naukowa.

[3] Cassirer, E. (1998). Esej o człowieku. Wstęp do filozofii kultury [An Essay on Man: An Introduction to a Philosophy of Human Culture]. Warszawa: Czytelnik.

[4] Copik, I. (2013). Pedagogika miejsca - kultura lokalna a kształtowanie się tożsamości współczesnego człowieka [Pedagogy of place - local culture and the formation of the identityof modern man]. Prace Naukowe Akademii im. Jana Długosza w Częstochowie - Pedagogika [Scientific Works of Academy of Jan Dlugosz in Czestochowa - Pedagogy], 22, 179-189.

[5] Giroux, H. A., \& Witkowski, L. (2010). Edukacja i sfera publiczna. Idee i doświadczenia pedagogiki radykalnej [Education and public sphere. Ideas and experience of radical pedagogy]. Kraków: Impuls.

[6] Godlewski, G. (2008). Animacja i antropologia: następna generacja [Animation and anthropology: next generation]. In: I. Kurz (Ed.), Lokalnie: animacja kultury/community arts [Local: cultural animation/community arts] (pp. 4-13). Warszawa: Uniwersytet Warszawski.

[7] Godlewski, G., (2005). Potężne zbiorniki znaczeń - wywiad z dr. Grzegorzem Godlewskim [Powerful tanks of meanings - interview with Grzegorz Godlewski PhD], Op.cit, 24-25. 6-7.

[8] Grochowski, M. (2013). Wstęp do wydania polskiego [The introduction for polish edition]. In: Ch. Landry (Ed.), Kreatywne miasto. Zestaw narzędzi dla innowatorów miejskich [Creative city. A toolkit for urban innovators] (pp. 9-22). Warszawa: Narodowe Centrum Kultury.

[9] Hall, E. T. (1990). The Hidden Dimension. New York: Anchor Books.

[10] Heidegger, M. (1975). Poetry, Language, Thought. New York: Harper Perennial.

[11] Kędziorek, A., Springer, F., \& Smaga, J. (2014). Dom jako forma otwarta. Szumin Hansenów [A home as an open space. The Hansens Szumin]. Kraków: Karakter.

[12] Kłosowski, W. (Ed.). (2012). Kierunek kultura. Uwwaga na podmioty! [The culture direction. Note the entities!]. Warszawa: Mazowieckie Centrum Kultury i Sztuki.

[13] Kopczyńska, M. (1993). Animacja społeczno-kulturalna. Podstawowe pojęcia i zagadnienia [Socio-cultural animation. Basic concepts and issues]. Warszawa: Centrum Animacji Kulturalnej.

[14] Kurantowicz, E. (2006). Badacz i mała społeczność lokalna. Proces badania jako zmaganie się $\mathrm{z}$ granicami [The researcher and small local community. The research process as a struggle with boundaries]. In: M. Mendel (Ed.), Pedagogika miejsca [Pedagogy of space] (pp. 78-87). Wrocław: Wydawnictwo Naukowe DSWE.

[15] Litwinowicz, M. (2008). Kultura czynna [Active culture]. In: I. Kurz (Ed.), Lokalnie: animacja kultury/community arts [Local: cultural animation/cumminity arts] (pp. 15-34). Warszawa: Uniwersytet Warszawski.

[16] Markowski, M. P. (2011). Humanistyka: niedokończony projekt [Humanities. Unfinished project]. Testy Drugie, 6. 13-28.

[17] Marszałek, M. (2007). Pamięć, meteorologia i urojenia. Środkowoeuropejska geopoetyka Andrzeja Stasiuka [Memory, meteorology and illusions. The Central European geopoetics of Andrzej Stasiuk] . In: M. Czermińska, M. Meller, P. Fliciński (Eds.), Literatura, kultura i język polski w kontekstach $i$ kontaktach światowych [Literature, culture and Polish language in contexts and contacts worldwide] (pp. 539-548). Poznań: Wydawnictwo Naukowe UAM

[18] Mendel, M. (2006). Pedagogika miejsca i animacja na miejsca wrażliwe [Pedagogy of space and animation sensitive to place]. In: M. Mendel (Ed.), Pedagogika miejsca [Pedagogy of place] (pp. 21-37). Wrocław: Wydawnictwo Naukowe DSW. 
[19] Męczkowska, A. (2006). Locus educandi: wokół problematyki miejsca w refleksji pedagogicznej [Locus educandi: on the problems of space in the pedagogical reflection]. Edukacja, 1. 20-32.

[20] Ossowski, S. (1984). O ojczyźnie i narodzie [About homeland and nation]. Warszawa: PWN.

[21] Rakowski, T. (Ed.). (2013). Etnografia/animacja/sztuka. Nierozpoznane wymiary rozwoju kulturalnego [Etnography/animation/art. Unknown dimension of cultural development]. Warszawa: Narodowe Centrum Kultury.

[22] Rybczyński, W. (2014). Jak dziata architektura. Przybornik humanisty [How does the architecture work? The tools for humanist]. Kraków: Karakter.

[23] Rybicka, E. (2008). Od poetyki przestrzeni do polityki miejsca. Zwrot topograficzny w badaniach literackich [From poetics to the politics of a place. Topographic turn in literature studies]. Teksty Drugie, 4, 21-38.

[24] Soja, E. W. (1996). Thirdspace: Expanding the Geographical Imagination. Malden: Blackwell.

[25] Springer, F. (2013). Wanna z kolumnada. Reportaże o polskiej przestrzeni [The bath with a collonade. Reports on Polish space]. Wołowiec: Wydawnictwo Czarne.

[26] Tuan, Y. (2001). Space and Place. The Perspective of Experience. Minneapolis-London: University of Minnesota Press.

[27] Węglarz, S. (2003). Karpaty jako pogranicze spotęgowane. Wstęp do karpatologii [Carpathians as a magnified borderland. Introduction to Carpathiology]. In: J. Kamocki, K. Kwaśniewicz, \& A. Spis, Pogranicza kulturowe i etniczne w Polsce [Cultural and ethincal borderlands in Poland] (pp. 23-24). Wrocław: Polskie Towarzystwo Ludoznawcze - Uniwersytet Wrocławski.

[28] Witkowski, L. (2001). Dwoistość w pedagogice Bogdana Suchodolskiego [Duality in Bogdan Suchodolski pedagogics]. Kraków: Wydawnictwo Uniwersytetu Jagiellońskiego. 